\title{
POLITICS IN NURSING: AN ESSENTIAL LEARNING FOR POSTGRADUATE STUDENTS
}

\author{
Andrée-Anne Bérubé1, Audrey Frenette', Clémence Dallaire², Elizabeth Bernardino²,
} Julie Blanchet ${ }^{1}$, Sophie Pomerleau ${ }^{4}$

\begin{abstract}
In Canada, as elsewhere, nurses must face many challenges if they want to participate as an influential group within health care organizations, but there are some facilitators; among them are the ability to analyze the context, issues and the right course of actions from a political perspective. This article shares the learning outcomes of postgraduate students during a seminar on policies related to nursing services administration at Université Laval, Québec, Canada. The aim of this article is to present the learning achieved from themes and issues discussed in the seminar and introduce tools for political analysis that are useful to draw the current state of nursing in the healthcare system. At the end of the seminar, the learning achieved allowed students to comprehend different elements that must be taken into account to assess the current situation concerning important issues for the nursing profession and consider courses of action to influence their evolution.
\end{abstract}

DESCRIPTORS: Health Postgraduate Programs; Nursing; Politics.

\section{POLÍTICAS EM ENFERMAGEM: UM APRENDIZADO ESSENCIAL PARA ESTUDANTES DE PÓS-GRADUAÇÃO}

RESUMO: No Canadá, como em outros lugares, enfermeiros devem enfrentar muitos desafios caso queiram participar como um grupo que influencia em organizações de cuidados em saúde. Contudo, existem alguns facilitadores, entre eles estão a habilidade de analisar o contexto, assuntos e percurso correto de ações sob a perspectiva política. Este artigo compartilha o resultado de aprendizado de estudantes de pós-graduação durante um seminário em politicas relacionadas aos serviços de administração de enfermagem na Universidade Laval, Quebec, Canadá. O objetivo deste artigo é apresentar o aprendizado alcançado sobre temas e assuntos discutidos e introduzir ferramentas para análise política, úteis para descrever a atual posição de enfermagem no sistema de saúde. No final do seminário, o aprendizado permitiu aos estudantes compreender diferentes elementos que devem ser considerados para avaliar a atual situação no que diz respeito a assuntos importantes para a profissão, e considerar percursos de ação para influenciar seu desenvolvimento. DESCRITORES: Programa de Pós-graduação em Saúde; Enfermagem; Política.

\section{POLÍTICAS EN ENFERMERÍA: UN APRENDIZAJE ESENCIAL PARA ALUMNOS DE POSGRADO}

RESUMEN: En Canadá, como en otros sitios, enfermeros deben pasar por muchos desafíos si desean participar como un grupo que influencia organizaciones de cuidados en salud. Sin embargo, hay algunos facilitadores, entre los cuales están la habilidad de analizar el contexto, asuntos y camino correcto de acciones bajo la perspectiva política. Este artículo comparte el resultado del aprendizaje de estudiantes de posgrado durante un congreso de políticas relacionadas a los servicios de administración de enfermería en la Universidad Laval, Quebec, Canadá. El objetivo del artículo fue presentar el aprendizaje alcanzado acerca de temas y asuntos discutidos así como introducir herramientas para análisis político, útiles para describir la actual posición de la enfermería en el sistema de salud. En el final del evento, el aprendizaje permitió a los estudiantes comprender diferentes elementos que deben ser considerados para evaluar la actual situación acerca de asuntos importantes para la profesión, y considerar caminos de acción para influenciar su desarrollo. DESCRIPTORES: Programa de posgrado en salud; Enfermería; Política.

\footnotetext{
${ }^{1}$ Nurse. Postgraduate student, master's degree at Université Laval, Quebec- Canada.

${ }^{2}$ Nurse. Professor at Faculté des Sciences Infirmières - Université Laval, Quebec- Canada.

${ }^{3}$ Nurse. PhD Nursing Science. Professor at Universidade Federal do Paraná, Paraná- Brazil.

${ }^{4}$ Nurse. Postgraduate student, doctoral degree at McGill University, Quebec- Canada.
}

Autor correspondente:

Recebido: 08/01/2013

Sophie Pomerleau

Aprovado: 04/10/2013

Université Laval

avenue de la médecine, 1050 - Québec-Canadá

E-mail: sophie.pomerleau@mail.mcgill.ca 


\section{INTRODUCTION}

For a decade, the Faculty of Nursing at Université Laval (Québec, Canada) has been offering a seminar on policies related to nursing services administration. The seminar was one of four seminars offered in the context of the Faculty's participation in the FERASI Center£, a consortium of faculties and schools of nursing from four different universities. The FERASI center was established to promote and support leadership development in nursing services administration through training, research and transfer of expertise and knowledge. The seminar introduces the students to the basic principles of political analysis, presents the social and normative foundations of political action and provides conceptual and practical tools for the analysis of public policies. The content focusses particularly on policies related to nursing and the political issues they are facing. We deem it important to share this learning because we believe it not only useful, but necessary to succeed in a postgraduate program in nursing.

The several themes discussed during the seminar help us to better understand public health policies, the influence of the government on health care and recognize the influence of nursing on the political.

PUBLIC POLITICS IN HEALTH CARE, THE ROLE OF THE STATE AND POLITICAL ANALYSIS TOOLS

First, we learned that the derivation of terms related to the term "politics" have several meanings, and that it is important to understand the difference between them. For instance, politics must be understood as the electoral processes aiming at being elected whereas policies must be understood as the underlying rules conducting institutions and governments ${ }^{(1)}$. As for political, it must be understood as power issues affecting all aspects of life within a society and refers to the use of influence and power among some stakeholders ${ }^{(2)}$.

At the beginning of the seminar, we discussed the role of the state in health care, particularly when the health care system is public such as those found in federal states like Canada and Brazil.

In Canada, the role of the state has been shaped by numerous issues faced by the society, issues that contributed to gradually transfer nursing from private care to a public system. Before, health care was entrusted to families, close entourage, parishes and communities ${ }^{(3)}$. Then came the Great Depression and health care has been reorganized, notably by adopting sanitary measures to counter epidemics. As the society became more industrialized, health care has been entrusted to organizations continuously specializing that were concerned by curative approaches.

Over the years, health care has been entrusted entirely to the state and decisions are taken by an increasingly centralized body. In the 1980s, governments started to focus on the cost of health care. In in 1984, federal government adopted Canada Health Act combining the funding of provinces' health services based on the five following standards: public management, integrality, universality, transferability and accessibility ${ }^{(3)}$.

Discussing the context in which states began reforming health care helped us comprehend how complicated the processes of identifying elements that would be subjected to reforms really is, not to mention the planning and the implementation of those reforms. Stakeholders with their perspectives, representations, interests and values have a determining influence on the course of a reform. They can influence the how and when a particular issue - that they are facing privately - might become a priority. To ensure that a problem occurring in a private sphere become a reform in the health care system, it has to escalate to a point where it becomes a social issue, then a public issue to finally reach the politico-administrative sphere ${ }^{(4)}$. Moreover, some key players in health care systems are described by the term "iron triangle" which consists of the state, the medical profession and economic experts ${ }^{(5)}$.

Although governments consult the public and experts prior to the implementation of a reform, the success of the implementation depends on the ability of a government to assess, first, the constraints that they will have to face ${ }^{(5)}$. In Canada, the renewal of the funding agreement between the provinces and the federal government regarding health care is due in 2014 and it is therefore an opportunity for stakeholders to take a stand and take action to influence decisions. We examined how the nursing profession can seize this opportunity by using the political to enforce its views on the health care system. We also learned the importance of remaining cautious as well as carefully analyse the context before taking the floor. It helps target interventions, thus maximizing the chances of success and political analysis grids are valuable strategic tools in this regard.

A political analysis grid is a tool that allows us to examine the political process or certain dimensions of the process in order to understand and explain it, and 
understand the impact of policies. While familiarizing ourselves with the grids in the seminar, we found that they often target the analysis of a particular aspect of a problem and that it may be advantageous to use more than one to achieve a more comprehensive analysis or an analysis better suited for the nature of the problem. Some grids can be used to study the process of elaboration/adoption of public policies consisting of the institutional, political, normative and cognitive dimensions in which coalitions of stakeholders emerged from a system of common beliefs and values ${ }^{(6)}$ while others focus on the relative power of stakeholders and assess the chances of success of a project ${ }^{(7)}$. One of the grids is useful to analyze the transferability of a public policy from a country to another ${ }^{(8)}$, whereas another can be used to analyse the reform process of a health care policy ${ }^{(9)}$. In sum, these grids can be used complementarily with one another depending on the aspects of a situation we want to examine.

In the seminar, each of us had to use a grid to analyze a political issue linked to both the nursing profession and our research project. For example, a student had to analyze the computerized patient record, a second one the implementation of home care and the last one, the origin of Quebec health care system reorganization. We conducted brief analyses drawing on our knowledge of the case, personal and professional experiences and literature and the analytical grids were useful to achieve an in-depth comprehension of the political, as they helped us understand the dynamics and stakeholders involved in each of these issues.

\section{NURSE POLICIES/INFLUENCE OF NURSING ON POLICIES}

In the seminar we discussed the political influence of nursing. The fact that nurses are not represented in the "iron triangle" mentioned above, combine to their impression of having little political power was opposed to the fact that nursing has made political gains, thus nurses have had and could have political influence.

In Quebec (French speaking province of Canada) some actions have laid the groundwork for a possible influence of nursing in health care. Following the board of inquiry on health in the late 1960s, Quebec government decided to create the Office des professions du Québec under the Department of Justice to ensure the protection of the public and monitor the competence of professionals(10). Nurses regrouped under the leadership of the Ordre des infirmières et infirmiers du Québec (OIIQ) in 1973, a professional order that establishes the legitimacy of nurses within a profession whereas the Nurses Act describes their scope of practice ${ }^{(10)}$. Nurses are thus in a better position under these laws, not only are they legitimized in their profession, but they are also entitled to send representatives to participate in negotiations surrounding health reforms. These gains common to different professions are assets for each of them.

In the early 1990s, a redesign of the Act respecting health services and social services brought the addition of the council of nurses - an official nursing consultative instance - to the organizational structure of all public health facilities in Quebec. The mandate of the council is to make recommendations to the Board of directors and chief executives on matters related to the quality of care ${ }^{(11)}$ Through the council, nurses gain an official body allowing them to express their views in their health facility. The addition of the council and its operation is a result of concerted efforts by the nursing professions in Quebec.

Now, even though some gains were made, we realized during the seminar that a certain political influence on health care requires acquisition of knowledge on policies and an ability to use analytical tools. We also realized that the political is not exclusively reserved for nurse representatives; every nurse has a role to play in the political to influence decisions. Therefore, to improve the influence of nursing, nurses must play the political game or be able to change the reference points of the political game (the dominant value system that sets the rules of the game) ${ }^{(12)}$. Improvement of nursing influence in political decisions affecting the profession can only be achieved through nurses' collective and concerted actions. We believe that political analysis, through analytical tools, enables awareness of usual reference points where nurses' perspective is absent (e.g. the iron triangle) and allows identification of strategies to influence effectively political decisions.

\section{THE EXTENT OF THE EXPERIENCE: TOWAR- DS A CONCLUSION}

At the end of the seminar, used as a learning skill for nursing postgraduate students, we came to the conclusion that the political is a complex and dynamic element. After discussions about the evolution of our health care system, current issues related to our nursing practice and nursing influence on health care policies, we have now a better understanding of the challenges 
faced by nurses trying to act as an influential group within health institutions. Political analyses conducted using analytical tools, allow a comprehension of the socio-political context and stimulate our reflections regarding our role as an individual and collective political stakeholder in current and future decisions. In sum, the learning achieved allows us now to examine our practice with a critical eye.

In Quebec, political analysis is barely mentioned in the initial training of nurses which can explain why the influence of nurses in health care is still suboptimal. Progress in Quebec in the last decades however, allows us to appreciate the collective efforts made by our profession.

In conclusion, to discuss policies in a graduate seminar allowed students to better understand the policy context and to share their perspective while applying it to the nursing profession. The richness and pertinence of this learning experience, as perceived by the participants, contributed to upgrade their academic preparation to a more contemporary level of education. The outcome of this learning experience could be a source of inspiration for Brazilian nurses and stimulate them to engage in similar analysis and sharing of perspective about their own political context. Similarly, they could benefit to discuss their conclusions and lessons with others from different political contexts, as suggested by the learning of the participants described in this article.

\section{REFERENCES}

1. O'Neill M, Gagnon F, Dallaire C. La, les le politique: trois manières d'aborder l'action politique en santé communautaire. In: Carroll G. (dir). L'intervention en santé communautaire; 2006. p. 113-28.

2. Dallaire C. L'action politique: une stratégie pour l'engagement professionnel. In: Dallaire C. (ed). Le savoir infirmier: au coeur de la discipline et de la profession infirmière. Boucherville: Gaétan Morin; 2008. p.455-80.

3. Bergeron P, Gagnon F. La prise en charge étatique de la santé au Québec : émergences et transformations. In: Lemieux V, Bergeron P, Bégin C, Bélanger G. Le système de santé au Québec. Organisations, acteurs et enjeux. Ste-Foy : Les Presses de l'Université Laval; 2003. p. 7-33.

4. Knoepfel P, Larrue C, Varone F. La mise à l'agenda politique. In: Analyse et pilotage des politiques publiques. Genève : Helbing et Lichtenhahn; 2001. p. 142-71.
5. Forest P-G, Bergeron KM. Les politiques de réforme du système de santé dans cinq fédérations: une analyse de travaux scientifiques récents. In: Imbeau L. Politiques publiques comparées dans les états fédérés. L'Allemagne, l'Australie, le Canada, les États-Unis et la Suisse. Québec: Les Presses de l'Université Laval; 2005. p.59-90.

6. Jenkins-Smith HC, Sabatier PA. Evaluating the Advocacy Coalition Framework. Journal of Public Policy.1994;14(2):175-203.

7. O'Neill M, Roch G, Boyer M. Petit manuel d'analyse et d'intervention politique en santé 2.ed. Québec : Les Presses de l’Université Laval; 2011.

8. Turgeon J, Gagnon F, Michaud M, Tremblay S. Le transfert de politiques publiques et l'évaluation d'impact sur la santé. Québec: GÉPPS; 2008. Available: http://www.gepps.enap.ca/207/serie_transfert_de _ connaissances.enap.

9. Hackey RB. The politics of reform. Journal of Health Politics, Policy \& Law. 2000;25(1): 211.

10. Labarre K, Dallaire C. L'exercice infirmier et le système professionnel. In: Dallaire C. (ed). Le savoir infirmier: au coeur de la discipline et de la profession infirmière. Boucherville: Gaétan Morin; 2008. p.341-57.

11. OIIQ. Conseil des Infirmières et Infirmiers : le pouvoir et la force du CII reposent sur l'implication des infirmières et infirmiers; 2012. Available: http:// www.oiiq.org/lordre/partenaires-infirmiers/conseildes-infirmieres.

12. Antrobus S. An Analysis of nursing in context: the effect of current health policy. Journal of Advanced Nursing.1997;25:447-53. 